ledge. One of his distinguishing characteristics was his readiness to tell everything he knew to any naturalist engaged in the investigation of the departments of zoology in which he himself had worked. He was a keen observer rather than a trained naturalist. He published little himself, but he contributed rich materials to those who knew how to make the best use of them. He was consequently a valued correspondent of many of the leading naturalists of his day, who gladly acknowledged their indebtedness to his generous aid. Nor were his observations confined to the living things of the existing creation; he searched the rocks around him for traces of former plants or animals, and found them in places where no one had ever seen or suspected them before. His keen eye detected the first relics of fossil fishes in the Devonian rocks of Devonshire, and when, after his transference to the north of Scotland in 1849 , he had an opportunity of looking at the limestones of Durness, he soon brought to light a series of fossils which, in the hands of Murchison and Salter, proved of the utmost value in fixing the geological age of the rocks of the North-West Highlands. After his retirement from the public service he went to reside in Edinburgh, and devoted himself with all his old enthusiasm to the exploration of the fossil flora of the Carboniferous rocks of that neighbourhood. Nothing seemed ever to escape his notice, and hence even from the quarries and sections where many a practised eye had preceded his own he was able to glean materials which no one but himself had noticed. In recognition of his important services to the cause of natural history, the Royal Society of Edinburgh in 1875 awarded to him the Neill Gold Medal. His health has for some time past been failing, and he has now gone to his rest with the affectionate regrets of all to whom the progress of natural science in this country is dear. His son, Mr. B. N. Peach, of the Geological Survey, with all his father's enthusiasin and more than his father's range of acquirement, will, we hope, for many a long year, preserve among the naturalists of this country a family name that is familiar as a household word.

\section{PROFESSOR EDWARD MORREN}

CHARLES JAMES EDWARD MORREN, whose death on the 28 th ult. we announced in our last issue, was the son of Charles Morren, a Professor in the University of Ghent, and was born in that city in 1833 . Shortly afterwards the father removed to Liege as Professor of Botany. The son, Edward, as he was usually called, was educated for the law, but evincing a strong tendency towards the natural sciences and chemistry, took his degree in the Science Faculty with much distinction. Owing to the ill-health of the father, Edward Morren was early called on to undertake the professorial duties, but the continuation of his licence to teach was made conditional on his undergoing a "special" examination for the Doctorate. This was the occasion of the publication of his dissertation on green and coloured leaves, by which he first became known to the botanists of Europe. After the death of Charles Morren, in 1858 , the son was appointed in the father's stead, and from that day to this, the aim of the son seemed to be to walk in the steps of his father, and to complete and extend his work. Both devoted themselves not only to botany but to chemistry, and in particular to horticulture and agronomy. Both were imbued, as so many of the Belgian savants are, with an ardent patriotism which led them to devote their science to the practical good of the nation, and to hold up to honour and respect the work of their celebrated predecessors. Hence, from father or son, or both, we have memoirs of Dodoens, of de l'Obel, of de l'Escluse, of Fuchs, and other worthies of Flemish nationality.

Both were impressed with the necessity of extending and adapting to the necessities of the times the system and the means of botanical education. The Botani. cal Institute of Liége, which Edward Morren lived to found and to see completed, was but the modified outcome and extension of the plans and schemes originally proposed by the father. The result is that Liége is now equipped with a compact and well-ordered laboratory for botanical tuition and research, such as some of our own Universities might envy. In order to perfect this institution Morren availed himself of his frequent travels to study the method of instruction followed in the Universities of Germany, and the organisation of the scientific establishments of Holland, Paris, London, and other centres. With his professorial work, his ceaseless duties in connection with official horticulture and the publication of the Belgique Horticole, Edward Morren necessarily found little time for the preparation of any separate work, but his memoirs and academic dissertations are numerous. The most important of them, as may be gleaned from what has been said, referred to questions of chemistry and vegetable physiology. A paper published in this country in the Report of the London Botanical Congress, I 866, comprises a most elaborate investigation into the action of sulphurous acid and other vapours on plants.

His academical discourses and popular lectures were remarkable both for their method and their matter. With the fluency and elegance of style of a practised orator, Morren combined the fulness of knowledge and accuracy of exposition of a man of science. Botanists, however, were looking forward with expectancy to a monograph of the Bromeliaceæ from his pen. It was known that the Professor had been accumulating for many years material for this purpose. His collection of living examples is, we believe, the largest and best selected in existence, and the materials in his herbarium and very extensive library (the most complete of its kind in Belgium) are in their way equally remarkable. Beyond detached fragments, however, Morren published little on this curious family.

Death has overtaken him, as it did his father, when little or not at all beyond the prime of life, and it has caused a void which only those who knew the warmhearted, genial, liberal-minded Professor can fully appreciate.

\section{THE WEATHER}

O

VER the greater part of the British Islands last month was one of the coldest Februarys on record, the mean temperature at Greenwich being only $33^{4} .8$, or $6^{\circ} .8$ below the average of the month. Throughout Great Britain generally, from the Grampians to the Channel, temperature was from about $5^{\circ} \circ$ to $7^{\circ}$. O below the means of the stations. But in the northern and western divisions of these islands temperature was only from about $2^{\circ} \circ$ to $3^{\circ} 5$ below the monthly averages. This difference was mainly occasioned by the distribution of temperature during the second week of the month, owing to the higher temperature in the north and west accompanying the storms which prevailed in the far north during the time. Thus during the week ending February I3, the mean temperature of Parsonstown was $43^{\circ} 5$, whilst at Oxford it was so low as $33^{\circ} \%$, or nearly $10^{\circ}$ lower.

From the middle of February, however, to the memorable snowstorm in the beginning of March, the weathermaps of Europe presented several remarkably persistent noteworthy features. The commencement of the period was marked at the Ben Nevis Observatory by forty-eight hours of singularly dry clear weather, such as occurs in connection with anticyclones and the settled weather attendant on them. Eastern and Northern Europe was now even more pronouncedly than it had been in the earlier part of the month the theatre of a widely. extended anticyclone, which slowly shifted its position from day to day, and sent out from its central regions winds in all 
directions, differing much in their climatic qualities. On the other hand, Western and Southern Europe was marked by an atmospheric pressure persistently and greatly lower, with an absence of anything approaching a cyclone-usually a characteristic feature of the weather at this season - if we except a cyclone, not very decidedly marked, that appeared in the Bay of Biscay on February 25 , and thence passed slowly eastwards across Italy and Greece, towards Asia Minor, which was reached on March 2.

The inevitable consequence of this distribution of atmospheric pressure was a prevalence of calms and of easterly and northerly winds over the Continent, with low temperatures. For five days, ending February 19, the anticyclone had its centre near Moscow, during which time the barometer, at $32^{\circ}$ and sea-level, rose to $30^{\circ} 965$ inches. Meanwhile temperature steadily fell, and $-7^{\circ} \cdot 6$ was recorded at Moscow on the morning of the Igth. The anticyclone thence advanced northward to the White Sea and westward to the Gulf of Bothnia, a pressure of $30^{\circ} 96 \mathrm{I}$ inches being recorded at Haparanda on the $22 \mathrm{nd}$, and $30^{\circ} 922$ inclies at Uleaborg, in Lapland, on the 24th ; and thereafter southward to Stockholm with a pressure of 30.603 inches on the 28 th, to Riga with a pressure of 30.742 inches on March 1 , and to Charkow with a pressure of $30^{\circ} 398$ inches on the 2 nd. The central regions of the anticyclone were throughout, as happens at this season, marked by unusually low temperatures, the lowest being - $16^{\circ} .8$ on the $23 \mathrm{rd}$ and $-18^{\circ} .8$ on the 24 th at Archangel, and $-15^{\circ} 5$ on the following morning at Haparanda, these temperatures being about $30^{\circ}$. 0 below the average for this time of the year at these places.

The weather-maps show that an important change had already set in on the morning of the last of February, the curvings of the isobaric lines pointing to a cyclone to the north-east of the White Sea, and to another cyclone advancing to the south-west of the British Islands. The anticyclone was thus now surrounded by three cyclones, located respectively near the White Sea, to the south-west of the British Islands, and in the Mediterranean. On the morning of March I the most northern of the cyclones had travelled somewhat to westwards, and the other two to eastward; and these respective movements were continued on the following day. In the meantime the anticyclone had greatly shrunk in breadth, and by the morning of the 2nd, when the snowstorm raged most fiercely over an unusually extensive breadth of country, it lay as a narrow tongue of high pressure westwards over Scanclinavia, and, meteorologically considered, perilously close on to the cyclone whose centre was then about the Humber. It necessarily followed, from the contiguity of the high-pressure area to the cyclone on its north side, that the storm passed across the British Islands with uncommon slowness, thus prolonging its continuance in Great Britain; and that the steepest gradients were formed in the north-east quarter of the cyclone, - a rather unusual feature of the storms of NorthWestern Europe,- thus exposing North Britain to one of the worst easterly gales of recent years.

Some snow fell in a few places on Sunday, but on Monday it fell in almost all parts of England, the fall being particularly severe in North Wales and the northern counties. The Furness and Wigtownshire railway lines were blocked and traffic suspended, a circumstance that has not occurred since these railways were opened, which as regards the Furness line is twentyseven years ago. In the more southern counties the storm was not quite so severe, and as the day advanced the snow changed to sleet and at last to heavy rain. On the Tuesdav the storm spread northwards over all Scotland, and raged with a fury altogether unexampled. () wing to the fineness of the snow-particles and the force of the wind, snowdrifts in many places accumulated in a rlegree quite unparalleled, and all transit was seriously paralysed. The most. serious railway block occurred on the East-Coast line, and it was computed that thirty trains of various sorts were snowed up between Newcastle and Berwick. Letters carried by the London Monday mail were not delivered in Edinburgh till Friday morning. The sensation produced by the rapidly-driven snowparticles on the face resembled the sharp pricking of a shower of needles; and it was remarked that the effect of the snow-drift on the eyes gave the feeling which would be produced by the spray of dilute nitric acid. As respects the singular character of the snowfall, it may be suggested that it was in some way connected with the remarkable meteorological conditions described above as having overspread Eastern and Northern Europe during the fortnight preceding the storm, and the proximity of North Britain to the anticyclone when the storm raged in all its fierceness.

It is remarkable that, while the snowfall was large in many western as well as in eastern districts, it was comparatively light over the higher midland parts of Scotland, and that on Ben Nevis and surrounding mountains little snow fell. It is to be noted, however, that at the Ben Nevis Observatory the wind blew, not as is usual on such occasions, from a different direction, but from precisely the same direction as at lower levels, with a force, however, very greatly diminished, the mean wind-force for the day being estimated by Mr. Omond at only 4 of the Beaufort scale. For the week preceding the storm the mean pressure and temperature of the air at the Observatory were respectively $25^{\circ} 482$ inches and $14^{\circ} 9$; and at sea-level at Fort William, $30^{\prime} 154$ inches and $33^{\circ} \cdot 2$. This mean pressure at the Observatory is 0.046 inch in excess of what previous observations show to be the mean when the sea-level pressure and temperature of the air is as above. On the morning of the itorm the excess was double that of the previous week. It is these departures from the average in their relations to the cyclones and anticyclones of this part of Europe that give the Ben Nevis observations their great significance.

\section{NOTES}

IT will be remembered that the Paris Academy of Sciences on Monday week, after hearing Prof. Pasteur's account of the cases he has treated, appointed a Committee to consider the question of the establishment at Paris of a vast international hospital. On Monday last M. Vulpian communicated to the Academy the following proposals, unanimously agreed upon by the Committee:-(I) An establishment for the treatment of rabies shall be founded at Paris under the name of l'Institut Pasteur. (2) This Institution shall he open both to French subjects and to foreigners bitten by dogs or other rabid animals. (3) A public subscription is opened in France and abroad for the foundation of this establishment. (4) The employment of the funds subscribed shall be made under the direction of a Committee, consisting of Admiral Jurien de la Gravière, President of the Academy of Sciences; M. Bertrand, M. Vulpian, M. Marey, M. Paul Bert, M. Bichat, M. Charcot, M. Hervé Mangon, M. de Freycinet, M. Camille Doucet, M. Wallon, Vicomte Delaborde, M. Jules Simon; M. Magnin, Governor of the Bank of France; M. Christophile, Governor of the Crédit Foncier; M. Alphonse de Rothschild ; M. Beclard, Doyen of the Faculty of Medicine, and Perpetual Secretary of the Academy of Medicine; M. Brouardel, Professor to the Faculty of Medicine, and President of the Consultative Hygienic Committee of France; M. Gaucher, Professor to the Faculty of Medicine of Paris. (5) The subscriptions shall be received at the Bank of France and its branches, at the Crédit Foncier and its branches, and at the Public Treasury Offices. The names of all subscribers shall be inserted in the Fournal Officiel. 